\title{
PENGARUH PERHATIAN TERBAGI TERHADAP KESADARAN SITUASI
}

\author{
Prisca Dwi Ariana, Thomas Dicky Hastjarjo \\ Fakultas Psikologi, Universitas Gadjah Mada \\ Jalan Sosio Humaniora, Bulaksumur, Yogyakarta 55281, Indonesia \\ dickyh@ugm.ac.id
}

\begin{abstract}
The increasing number of traffic accident is caused by the decreasing of driver situational awareness. Divided attention is one of several factors that affect situation awareness. This experiment was to study the effects of listening to the music or reading short message sent to participant's mobile phone on participant's situational awareness while they drove car simulator. Thirty subjects were randomly divided into two groups, namely: (a) music group. The subjects were asked to listen to Ed Sheeran pop music when they drove city car simulator, and (b) mobile phone group. In this condition the subjects received and replied short message on their mobile phones at third, fifth, eighth, and tenth minutes during driving car simulator. Situational awareness was measured by SAGAT (Situation Awareness Global Assessment Technique). The simulation was stopped when SAGAT questionnaire was distributed to the subjects at fifth and tenth minutes. The t test statistical analysis showed that there was a significant difference in situation awareness between the two groups $(t=5.750 ; p=.001)$. Music group showed higher situation awareness than mobile phone group. The use of mobile phone while driving is more distracting attention than listening to music.
\end{abstract}

Keywords: situation awareness; divided attention; city car simulator; listening to the music; reading short message

\begin{abstract}
Abstrak
Kecelakaan mobil dapat diakibatkan oleh faktor kesadaran situasi pengendara mobil yang rendah. Kesadaran situasi dipengaruhi oleh perhatian yang terbagi para pengendara mobil. Perhatian sopir dapat terganggu jika harus melakukan kegiatan lain disamping kegiatan mengemudikan mobil. Penelitian ini bertujuan menguji pengaruh perhatian terbagi terhadap kesadaran situasi pengendara simulator mobil. Metode yang digunakan adalah eksperimen dengan tigapuluh subjek mengendarai simulator mobil dan terbagi menjadi dua kelompok (a) kelompok musik, selama mengemudikan simulator subjek diminta mendengarkan musik pop Ed Sheeran, dan (b) kelompok telepon genggam, selama mengendarai simulator subjek diminta membaca pesan singkat melalui telepon genggam pada menit ke 3,5,8 dan 10. Pengukuran kesadaran situasi dilakukan dengan memberikan kuesioner SAGAT pada menit kelima dan menit kesepuluh. Selama pengukuran kesadaran situasi maka simulasi dihentikan. Analisis yang digunakan adalah uji t yang membandingkan skor kesadaran situasi kelompok. Hasil penelitian menunjukkan terdapat perbedaan nilai kesadaran situasi yang signifikan diantara dua kondisi perlakuan $(t=5,750, p=0,001)$. Skor kesadaran situasi ketika mendengarkan musik lebih tinggi dibandingkan sekor kesadaran situasi ketika membaca pesan singkat melalui telepon genggam. Dapat disimpulkan bahwa menggunakan telepon genggam untuk membaca serta membalas pesan sambil mengemudi lebih menggangu perhatian pengemudi mobil dibandingkan mendengarkan musik pop.
\end{abstract}

Kata kunci: kesadaran situasi; perhatian terbagi; simulator mobil; mendengarkan musik; menerima pesan singkat

\section{PENDAHULUAN}

Transportasi merupakan salah satu bidang yang mengalami perkembangan sangat pesat. Badan Pusat Statistik (2016) melaporkan peningkatan jumlah alat transportasi darat atau kendaraan beroda empat selama tahun 2000-2013. Mobil merupakan alat transportasi yang paling tinggi jumlah peningkatannya. Peningkatan jumlah mobil ini dapat menyebabkan permasalahan yaitu kemacetan dan kecelakaan lalu lintas. 
Menurut World Health Organization (WHO) Indonesia menempati urutan kelima negara dengan jumlah kematian terbanyak akibat kecelakaan lalu lintas, namun Indonesia justru menempati urutan pertama peningkatan kecelakaan menurut data Global Status Report on Road Safety yang dikeluarkan WHO (Amanda \& Marbun, 2014). Indonesia dilaporkan mengalami kenaikan jumlah kecelakaan lalu lintas hingga lebih dari 80 persen.

Beberapa faktor menjadi pemicu terjadinya kecelakaan lalu lintas, diantaranya adalah faktor manusia (pengendara), kendaraan, jalan dan lingkungan (Departemen Perhubungan, 2006). Penelitian Treat dkk. (1979) menunjukkan bahwa faktor manusia merupakan penyebab utama kecelakaan lalu lintas sebesar 93\% serta bahwa perhatian yang kurang ketika mengendarai mobil adalah salah satu penyebab terjadinya kecelakaan lalu lintas tersebut. Hendricks, Feld, \& Freedman (1999) menyebutkan bahwa, 37,8\% dari 723 kasus kecelakaan disebabkan oleh ketidakfokusan dan kesalahan persepsi pengendara. Hal ini termasuk kondisi ketika seorang pengemudi melakukan dua kegiatan sekaligus (multitasking) ketika mengendarai mobil. Kegiatan lain yang sering dilakukan ketika sedang mengendarai mobil antara lain menggunakan telepon genggam, mendengarkan musik, atau berbincang dengan penumpang lain.

Penelitian mengenai keselamatan di jalan raya menunjukkan bahwa banyak sumber informasi yang mengalihkan perhatian dan mendorong resiko kecelakaan selama berkendara yang sebagian besar berasal dari telepon genggam seperti panggilan telepon (Alm \& Nilsson, 1995), dan pesan singkat (Drews, Yazdani, Godfrey, Cooper, \& Strayer, 2009). Penelitian survei yang dilakukan oleh Dibben dan Wiliamson (2007) menyebutkan bahwa kebiasaan mendengarkan musik tidak mengganggu dibandingkan berbicara dengan penumpang lain atau menggunakan telepon genggam saat mengendarai mobil. Penelitian North, Hargreaves, dan Hargreaves (2004) menunjukkan bahwa mendengarkan musik sering menjadi kebiasaan yang menyertai pengendara dan dianggap sebagai hal yang dapat membantu pengendara untuk meningkatkan konsentrasi.

Berangkat dari gambaran di atas, peneliti mencoba menggali mengenai pengaruh perhatian terhadap kesadaran situasional, khususnya perhatian yang terbagi ke dalam dua tugas. Permasalahan penelitian adalah "Apakah terdapat pengaruh perhatian terbagi terhadap kesadaran situasi pengendara mobil?" Tujuan utama penelitian ini adalah untuk merumuskan apakah terdapat pengaruh perhatian yang terbagi terhadap kesadaran situasional pengendara mobil. Penelitian ini diharapkan dapat memberikan manfaat praktis menambah kajian ilmu Psikologi mengenai pentingnya memiliki kesadaran situasi saat sedang mengendarai mobil sehingga diharapkan kesadaran situasi pengendara mobil dapat dioptimalkan untuk meminimalisir jumlah kecelakaan ataupun jumlah pelanggaran peraturan lalu lintas.

Konsep kesadaran situasional atau kesadaran situasi dari situation/situational awareness (makalah ini selanjutnya menggunakan istilah kesadaran situasi) dikembangkan sekitar pertengahan tahun 1980an dan mengalami perkembangan pesat di tahun 1990an (Endsley, 2000a) serta sampai kini masih terpakai (Lau, Jamieson \& Skraaning, 2013). Ensdley menjelaskan bahwa seorang operator, apakah dia pilot di kabin pesawat, pengawas radar di menara pengendali lalu lintas udara (ATC), petugas yang mengawasi kerja mesin di pabrik, atau seorang dokter ahli anestesi semuanya harus mempersepsi dan memahami berbagai informasi yang datang serta yang bersifat berubah sangat cepat.

Rumusan kesadaran situasi adalah:

"Persepsi mengenai unsur lingkungan dalam volume waktu dan ruang, pemahaman terhadap maknanya serta 
proyeksi terhadap statusnya di masa datang yang dekat" (Endsley, 2000a).

Kesadaran situasi dapat dibagi menjadi tiga level menurut Endsley (1995): (1) Level 1 Persepsi. Level pertama adalah persepsi terhadap tanda-tanda atau informasi dasar yang terdapat di lingkungan sekitar. Jika persepsi pengemudi terhadap sekitar tidak baik maka peluang menghasilkan gambaran yang salah mengenai kesadaran situasi akan meningkat; (2) Level 2 Pemahaman. Konstruk kesadaran situasi lebih dari sekadar persepsi, namun juga meliputi bagaimana orang memadukan, menginterpretasi, menyimpan dan menjaga informasi. Kesadaran situasi melibatkan proses mengintegrasikan banyak kepingan informasi serta menentukan relevansinya dengan tujuan; (3) Level 3 Proyeksi. Kesadaran situasi tingkat tertinggi adalah kemampuan meramalkan dinamika dan peristiwa situasi di masa datang. Kemampuan memproyeksikan dinamika serta peristiwa sekarang untuk mengantisipasi peristiwa di masa datang akan menelurkan keputusan yang akurat serta tepat pada waktunya. Pengalaman penelitian Endsley terhadap pilot, petugas menara lalu lintas udara, dokter, serta operator mesin di pabrik menunjukkan bahwa operator berpengalaman mendasarkan pada proyeksi kedepan, ini merupakan ciri khas seorang ahli atau expert (Endsley, 2000a).

Kesadaran situasi dapat diukur dengan empat cara (Moore \& Gugerty, 2010), yakni (1) Pengukuran subjektif, yakni bertanya kepada individu atau ahli dalam sebuah bidang untuk menentukan tingkat kesadaran situasional, (2) Pengukuran implisit, yaitu memberikan skenario yang mengandung informasi dan akan menghasilkan perilaku tertentu dari subjek kemudian menafsirkan perilaku tersebut, (3) Pengukuran eksplisit/langsung. Cara ini mengukur kesadaran situasi dalam melaksanakan tugas. Misalnya, metode querry (pertanyaan) atau disebut juga freeze probe technique yang dikembangkan berdasar tugas atau skenario serta akan mengukur kesadaran situasi operator dengan mengajukan pertanyaan yang berkaitan dengan skenario selama operator melaksanakan tugas itu. Selama pertanyaan tersebut diajukan maka pelaksanaan tugas operator dibekukan atau dihentikan sementara. Misalnya pengukuran SAGAT (Situational Awareness Global Assesment Tehnique/Teknik Asesmen Global Kesadaran Situasi) serta (4) Pengukuran fisiologis. Pengukuran fisiologis menyangkut pengukuran detak jantung, aktivitas otak serta gerakan mata. Penelitian ini memakai SAGAT untuk mengukur kesadaran situasi.

Menurut Endsley (1995) kesadaran situasi dipengaruhi oleh beberapa faktor di lingkungan eksternal seperti stres, beban kerja (workload), desain sistem (system design), kompleksitas sistem dan otomatisasi (automation). Beban kerja yang tinggi dapat menjadi stresor yang dapat memberikan dampak negatif bagi kesadaran situasional. Apabila jumlah informasi yang berlebihan disertai dengan jumlah beban tugas yang sangat besar maka kesadaran situasi akan mengalami penurunan. Misalnya pengemudi hanya memperhatikan informasi secara terbatas. Kesadaran situasi dapat juga dipengaruhi oleh faktor internal (Gugerty \& Tirre, 2000). Karakteristik individu yang berhubungan dengan kesadaran situasi antara lain, memori kerja (working memory), pemrosesan visual, pemrosesan temporal, kemampuan perseptual motorik.

Menurut Matlin (1998) perhatian adalah aktivitas mental yang terkonsentrasi dan Sternberg (1996) menyatakan bahwa perhatian adalah pemrosesan kognitif secara aktif terhadap sejumlah informasi terbatas dari banyak sekali informasi yang tersedia. Perhatian dapat dibagi menjadi beberapa jenis dengan konteks mengemudikan mobil di jalan raya (Wickens \& McCarley, 2008). Terdapat perhatian terbagi (divided attention) yakni merupakan perhatian yang harus dibagi kepada dua sumber informasi. Misalnya, pengemudi harus membagi perhatian kepada jalan di depan serta 
informasi di displai mengenai bensin yang masih tersedia di mobil. Pengemudi menyeleksi untuk mencurahkan perhatian ke satu tugas tertentu atau tugas yang lain biasanya diperlihatkan oleh skening visual. Indera mata si pengemudi mobil diarahkan kearah mana. Contoh lain ditingkat tugas, seorang sopir akan mempertahankan jalur sambil memahami berita dari radio atau mendengarkan musik.

Wickens (2008) mengembangkan model sumberdaya jamak (multiple resource theories) yang membagi pemrosesan informasi kedalam 4 (empat) dimensi, yakni (a) Tahap pemrosesan, (b) Kode pemrosesan, (c) Modalitas pemrosesan, dan (d) Saluran visual. Tahapan pemrosesan menunjukkan bahwa aktivitas persepsi serta kognisi (misal memori kerja) membutuhkan sumberdaya yang berbeda dengan aktivitas yang mendasari seleksi tindakan serta eksekusi tindakan. Kode pemrosesan menunjukkan bahwa aktivitas keruangan (spatial) membutuhkan sumberdaya yang berbeda dengan aktivitas bahasa atau verbal. Selanjutnya modalitas pemrosesan menyatakan bahwa persepsi auditoris membutuhkan sumberdaya yang berbeda dengan persepsi visual.

Adapun dimensi keempat adalah saluran visual. Saluran visual terbagi kedalam visi fokal serta visi ambien. Visi fokal terutama bagian fovea yang mendukung rekognisi objek serta persepsi ketajaman seperti dalam membaca bacaan dan merekognisi simbol. Visi ambien yang terdistribusi diseluruh medan visual terutama berkaitan dengan visi perifer yang bertanggung jawab terhadap persepsi orientasi serta gerakan. Atas dasar teori Wickens (2008) ini maka dapat diprediksi jika mengendarai mobil yang terutama membutuhkan sumberdaya visual sambil mendengarkan musik yang membutuhkan sumberdaya auditif akan tidak membahayakan dibanding dengan mengemudikan mobil sambil memainkan telepon genggam yang sama-sama menggunakan sumberdaya visual.
Mendengarkan musik saat sedang berkendara dianggap sebagai hal yang biasa dilakukan oleh pengemudi serta tidak mengganggu dibandingkan berbicara dengan penumpang lain atau menggunakan telepon genggam (Dibben \& Williamson, 2007). Penelitian yang dilakukan oleh North dkk. (2004) menyimpulkan bahwa mendengarkan musik saat berkendara dapat membantu meningkatkan konsentrasi. Apabila pengemudi mendengarkan musik saat berkendara, konsentrasi pengemudi mengalami peningkatan sehingga pengemudi memiliki kesadaran dan kewaspadaan yang tinggi terhadap lingkungan. Hasil penelitian survei yang dilakukan oleh Arya, Wahyuningsih dan Destriany (2004) menunjukkan bahwa tingkat kewaspadaan pengemudi lebih baik ketika mengendarai mobil sambil mendengarkan musik dibandingkan dengan yang tidak mendengarkan musik. Berkendara dengan mendengarkan musik dianggap tidak mengganggu dikarenakan saat pengemudi mendengarkan musik, visual pengemudi tidak terganggu sehingga pengemudi dapat tetap fokus dengan jalan raya. Mendengarkan musik ketika berkendara juga dapat membantu pengemudi menghilangkan rasa bosan, jenuh dan mengantuk ketika sedang berkendara yang dapat memicu kecelakaan lalu lintas.

Dapat disimpulkan bahwa melakukan kegiatan lain ketika sedang berkendara dapat membantu atau mengganggu perhatian pengemudi. Apabila perhatian pengemudi tergangu, maka kesadaran dan kewaspadaan pengemudi mengalami penurunan. Mendengarkan musik dapat membantu meningkatkan konsentrasi pengemudi dan menghilangkan rasa bosan, mengantuk pengemudi. Sedangkan, menggunakan telepon genggam ketika sedang berkendara dapat mengganggu pengemudi karena ketika sedang menggunakan telepon genggam visual pengemudi mengalami distraksi (gangguan) sejenak untuk melihat kondisi jalan serta lingkungan di sekitar mobil. 
Berdasarkan tinjauan pustaka yang telah diuraikan sebelumnya maka penelitian ini berujuan untuk menguji pengaruh perhatian terbagi terhadap kesadaran situasi saat berkendara. Lebih khusus, hipotesis yang diajukan dalam penelitian ini adalah "Kesadaran situasi pengendara simulator mobil akan lebih tinggi pada pengendara yang mendengarkan musik daripada pengendara yang membaca pesan singkat melalui telepon genggam".

\section{METODE}

Penelitian ini menggunakan metode eksperimen. Rancangan eksperimen adalah rancangan acak dua kelompok dengan pengukuran pasca perlakuan (Hastjarjo, 2014), dengan skema tersaji dalam Gambar 1.

\begin{tabular}{|lll|}
\hline $\mathrm{R}$ & $\mathrm{Xa}_{1}$ & $\mathrm{O}_{1}$ \\
$============$ \\
$\mathrm{R}$ & $\mathrm{Xa}_{2}$ & $\mathrm{O}_{2}$ \\
\hline
\end{tabular}

$\mathrm{R}$ = penempatan subjek secara acak kedalam kondisi perlakuan

$\mathrm{Xa}_{1}=$ mendengar musik

$\mathrm{Xa}_{2}=$ membaca pesan melalui telepon genggam

$\mathrm{O}$ = pengukuran kesadaran situasi dengan SAGAT

Gambar 1. Rancangan Acak Dua Kelompok dengan Pengukuran Pasca Perlakuan

Variabel independen penelitian adalah perhatian terbagi. Secara operasional perhatian terbagi dirumuskan sebagai kemampuan individu dalam memproses suatu informasi sekaligus ketika individu melakukan beberapa tugas dalam satu waktu Perhatian terbagi dimunculkan atau dimanipulasi dengan meminta subjek selain mengemudi mobil simulator mereka harus menjalankan tugas lain yaitu mendengarkan musik atau menggunakan telepon genggam untuk membaca dan membalas pesan singkat. Meskipun kegiatan lain yang diberikan peneliti kepada subjek penelitian berbeda namun bertujuan sama yaitu agar perhatian menjadi terbagi. Kegiatan lain tersebut dimunculkan dalam dua bentuk yaitu (a) mendengarkan musik genre pop dengan lagu dari Ed Sheeran yang diperdengarkan lewat headset di masingmasing telepon genggam selama simulasi mengendarai mobil berlangsung serta (b) membaca dan membalas pesan singkat melalui telepon genggam yang diberikan kepada responden empat kali selama simulasi berlangsung yaitu pada menit ketiga, kelima, kedelapan dan kesepuluh.

Variabel dependen penelitian ini adalah kesadaran situasi yaitu kemampuan mempersepsi, memahami lingkungan sekitar serta memproyeksikan pada masa yang akan datang pada saat mengendarai simulator mobil. Kesadaran situasi ini diukur melalui kuesioner Teknik Asesemen Global Kesadaran Situasional/ Situational Awareness Global Assesment Techniquel SAGAT (Endsley, 1995, 2000b). SAGAT terdiri dari 10 item pertanyaan mengenai kemampuan mempersepsi (misalnya, "Apakah ada kendaraan di belakang anda?"), 8 item pertanyaan kemampuan memahami (misalnya, "Apakah mobil di belakang anda lebih cepat atau lebih lambat dari kecepatan mobil anda?"), serta 7 item kemampuan memproyeksikan di masa datang (misalnya, "Apakah mobil di belakang anda bisa melewati anda?"). Jawaban subjek dalam SAGAT diberi nilai 1 (satu) apabila benar, kemudian diberi nilai 0 (nol) apabila jawaban salah. Diberlakukan toleransi untuk jawaban responden seperti estimasi kecepatan mobil $+/-5 \mathrm{~km} / \mathrm{h}$, artinya jika kecepatan sebenarnya adalah $30 \mathrm{~km} / \mathrm{h}$, maka jawaban responden dinilai benar pada kisaran angka $25 \mathrm{~km} / \mathrm{h}$ sampai $35 \mathrm{~km} / \mathrm{h}$. Sedangkan pertanyaan yang tidak dijawab akan dianggap salah.

Setiap jawaban benar akan dihitung untuk mendapatkan prosentase nilai dari masingmasing level kesadaran situasi sedangkan kesadaran situasi keseluruhan diperoleh dengan merata-ratakan nilai kesadaran situasi dari setiap level. Selanjutnya dilakukan transformasi data terhadap prosentase nilai dari masing-masing level kesadaran situasional dan kesadaran 
situasional secara keseluruhan. Transformasi data perlu dilakukan untuk data kesadaran situasional agar data dapat terdistribusi normal. Endsley (2000b) menyatakan bahwa transformasi data kesadaran situasional dapat menggunakan arcsine transformation, dengan persamaan sebagai berikut:

$$
\text { Xbaru }=\text { arcsine } \sqrt{ } \text { Xlama }
$$

Tabel 1 memberikan contoh skor kesadaran situasi subjek penelitian 1 yang berbentuk prosentase jawaban benar dan ditransformasikan ke data interval dengan rumus di atas.

Tabel 1.

Contoh Transformasi Data Kesadaran

Situasi dari Angka Prosentase ke Data Interval

\begin{tabular}{|c|c|c|c|c|c|}
\hline $\begin{array}{l}\text { Ketera } \\
\text { ngan } \\
\text { Data }\end{array}$ & $\begin{array}{l}\mathrm{Me}- \\
\text { nit } \\
\mathrm{Ke}\end{array}$ & $\begin{array}{l}\text { SA } \\
\text { Level } \\
1\end{array}$ & $\begin{array}{l}\text { SA } \\
\text { Level } \\
2\end{array}$ & $\begin{array}{l}\text { SA } \\
\text { Level } \\
3\end{array}$ & $\begin{array}{l}\text { SA } \\
\text { Kese- } \\
\text { luruh } \\
\text { an }\end{array}$ \\
\hline X lama & 5 & $\begin{array}{l}63,64 \\
\%\end{array}$ & $75 \%$ & $\begin{array}{l}71,43 \\
\%\end{array}$ & $\begin{array}{l}70,02 \\
\%\end{array}$ \\
\hline $\mathrm{X}$ baru & 5 & 0,92 & 1,05 & 1,01 & 0,99 \\
\hline
\end{tabular}

Gugerty (1997) telah membuktikan teknik SAGAT memiliki kehandalan yang baik untuk mengukur presentase kesalahan memori pada pengemudi mobil dan tingkat kesadaran situasi. Kemudian Endsley (2000) mengatakan bahwa teknik SAGAT terbukti memiliki validitas yang tinggi dan handal untuk mengukur kesadaran situasional. Validitas alat ukur SAGAT dalam penelitian ini ditentukan dengan validitas isi (content validity) melalui analisis rasional atau profesional judgment. Validasi ini bertujuan menentukan sejauh mana aitem-aitem tes mewakili komponen-komponen dalam keseluruhan kawasan isi objek yang hendak diukur (aspek representasi) dan sejauh mana aitemaitem mencerminkan ciri perilaku yang hendak diukur (aspek relevansi) (Azwar, 2015). Dengan menggunakan rumus Aiken's $\mathrm{V}$, koefisien validitas isi dihitung mendapatkan nilai terendah 0,8625 dan nilai tertinggi 1. Hal tersebut menunjukkan bahwa validitas isi SAGAT terpenuhi. Sedangkan reliabilitas pengukuran ditentukan dengan menggunakan perhitungan Alpha-Cronbach. Hasil uji coba alat ukur SAGAT terhadap 20 orang mahasiswa Universitas Gadjah Mada diperoleh nilai reliabilitas sebesar 0,865. Seluruh item SAGAT sejumlah 26 item tidak ada yang gugur, sehingga alat ukur siap digunakan untuk pengambilan data penelitian.

Adapun subjek dipilih secara purposif, yaitu berdasarkan ciri-ciri atau sifat-sifat tertentu yang dipandang mempunyai sangkut paut erat dengan ciri-ciri atau sifat-sifat populasi yang sudah diketahui sebelumnya (Hadi, 2015). Kriteria inklusi yang digunakan dalam memilih subjek adalah sebagai berikut: (1) mahasiswa, (2) berusia antara 20 hingga 25 tahun, (3) dapat mengendarai mobil, serta (4) memiliki SIM A. Subjek penelitian adalah 30 mahasiswa yang terdiri dari 19 laki-laki dan 11 perempuan berasal dari Perguruan Tinggi di Yogyakarta (UGM, UNY, UMY, UII dan UPN). Subjek dibagi secara acak menjadi dua kelompok, (a) kelompok mendengarkan musik sebanyak 15 mahasiswa, dan (b) kelompok membaca pesan singkat melalui telepon genggam sebanyak 15 mahasiswa.

Pengambilan data penelitian dilakukan selama dua minggu yaitu pada tanggal 10 Juli 2015 hingga 24 Juli 2015 di Ruang Penelitian 3 Laboratorium Ergonomika Teknik Industri Universitas Gadjah Mada. Alat yang digunakan dalam penelitian ini adalah city car driving simulator milik Laboratorium Ergonomika Teknik Industri Universitas Gadjah Mada. Waktu pengambilan data penelitian serta pelaksanaan eksperimen ditentukan berdasarkan kesepakatan antara subjek dengan peneliti. Peneliti dibantu oleh satu asisten peneliti. Pelaksanaan eksperimen mengikuti prosedur berikut. (a) Sebelum masuk ke ruang eksperimen asisten peneliti meminta subjek memilih sebuah lintingan kertas dari gelas untuk menentukan kelompok kondisi perlakuan (kelompok musik atau kelompok telepon genggam), (b) 
subjek duduk di simulator dan peneliti meminta subjek untuk mempersiapkan telepon genggamnya diletakan di atas meja dekat dengan responden. Jika termasuk kelompok musik, subjek diminta memasang/meng-install musik di telepon genggamnya. Jika masuk ke kelompok membaca pesan, subjek diminta mengaktifkan telepon genggam dan membalas pesan yang masuk. Peneliti menjelaskan tujuan simulasi yaitu untuk mengukur "kemampuan mengemudi". Peneliti dan asisten peneliti menjelaskan cara-cara menjalankan alat simulasi tersebut dan ketika responden sudah paham cara menjalankan alat simulasi, memahami penggunaan kemudi/steer, pengendali/controller simulasi serta indikator-indikator yang ada pada simulator, maka subjek diberi kesempatan berlatih menggunakan simulator mobil selama 10-15 menit, (c) eksperimen sesungguhnya berlangsung selama 10 menit dengan skenario lalu lintas normal.

Penentuan skenario simulasi dilakukan untuk menggambarkan kondisi nyata lalu lintas yang ada pada jalan raya dengan menggunakan software simulator mengemudi. Skenario penelitian ini dimulai pada lokasi yang sama pada tiap sesi dan selanjutnya diarahkan menuju lokasi yang lain pada simulator mengemudi. Skenario yang telah ditentukan tadi saling berhubungan dengan kuesioner SAGAT yang akan diajukan kepada responden.

Subjek kelompok mendengarkan musik diberikan dua tugas dalam waktu yang bersamaan yaitu mengendarai mobil sambil mendengarkan musik jenis musik pop. Musik diperdengarkan kepada subjek selama berlangsungnya simulasi. Musik akan diberhentikan oleh peneliti ketika masuk tahap pembekuan/freeze dimana responden diminta untuk mengisi kuesioner SAGAT. Pada kelompok membaca pesan singkat melalui telepon genggam, subjek diberikan dua tugas dalam waktu yang bersamaan yaitu mengendarai mobil sambil membaca pesan singkat melalui telepon genggam. Pesan singkat diberikan kepada subjek oleh peneliti pada menit ke-3 dan menit ke-5 selama simulasi berlangsung. Isi pesan dapat berubah tergantung pesan yang dikirimkan balik oleh responden. Isi pesan singkat secara umum yang diberikan kepada subjek adalah sebagai berikut: "Lagi dimana dan lagi apa? serta mau kemana?" e) Pemberian kuesioner SAGAT kepada responden dilakukan pada menit ke-5 dan menit ke-10.

Data dianalisis dengan uji $\mathrm{t}$, yaitu pairedsample t test dan independent sample t-test dengan menggunakan program SPSS 21. Uji $\mathrm{t}$ bertujuan untuk menguji ada atau tidaknya pengaruh variabel independen terhadap variabel dependen. Uji t pada dasarnya menunjukkan seberapa jauh pengaruh satu variabel independen secara individual dalam menerangkan variasi variabel independen (Ghozali, 2011). Sebelum melakukan uji t data telah lolos uji asumsi normalitas sebaran menggunakan Shapiro-Wilk serta homogenitas menggunakan Levene's test for equality of variance dengan nilai signifikansi di atas 0,05.

\section{HASIL DAN PEMBAHASAN}

Analisis pertama yang dilakukan adalah analisis uji t sampel berpasangan (pairedsample t-test) untuk melihat apakah terdapat perbedaan nilai kesadaran situasi pada menit ke-5 dan menit ke-10 pada perlakuan mendengarkan musik maupun menggunakan telepon genggam. Hasil analisis uji $t$ sampel berpasangan menunjukkan tidak terdapat perbedaan antara kesadaran situasi pada menit ke-5 dengan menit ke-10 pada perlakuan musik ( $t$ $=-1,498 ; p=0,075)$. Demikian juga tidak terdapat perbedaan antara kesadaran situasi pada menit ke-5 dengan menit ke-10 pada perlakuan telepon genggam $(t=0,241 ; p=$ 0,121).

Kemudian digunakan analisis uji t sampel independen untuk menguji hipotesis "Kesadaran situasi pengendara simulator 
mobil akan lebih tinggi pada pengendara yang mendengarkan musik daripada pengendara yang membaca pesan singkat melalui telepon genggam". Hasil analisis menunjukkan nilai mean atau rerata pada perlakuan mendengarkan musik 1,0120 dan nilai rerata kesadaran situasi pada perlakuan membaca pesan singkat melalui telepon genggam 0,8547. Nilai rerata kesadaran situasi perlakuan mendengarkan musik lebih tinggi dibandingkan nilai kesadaran situasi perlakuan membaca pesan singkat melalui telepon genggam dengan nilai signifikansi $(t$ $=5,750 ; p=0,001)$. Sehingga dapat disimpulkan bahwa terdapat perbedaan nilai kesadaran situasional secara signifikan di antara dua perlakuan secara keseluruhan, di mana nilai kesadaran situasi mendengarkan musik lebih tinggi dibandingkan dengan nilai kesadaran situasi membaca pesan singkat melalui telepon genggam.

Hasil analisis secara keseluruhan menunjukkan bahwa nilai kesadaran situasi pada perlakuan mendengarkan musik lebih tinggi dibandingkan nilai kesadaran situasional pada perlakuan membaca pesan singkat melalui telepon genggam. Hasil penelitian ini sesuai dengan penelitian survei yang dilakukan oleh Arya, Wahyuningsih, \& Destriani (2014) yang menyebutkan bahwa tingkat kewaspadaan (kesadaran situasi) seseorang lebih baik saat mengendarai mobil sambil mendengarkan musik dibandingkan dengan yang tidak mendengarkan musik saat mengendarai mobil. Hasil eksperimen ini sesuai dengan penelitian survei Dibben dan Wiliamson (2007) bahwa kebiasaan mendengarkan musik tidak mengganggu dibandingkan berbicara dengan penumpang lain atau menggunakan telepon genggam saat mengendarai mobil. Hal ini disebabkan karena menurut penelitian North, Hargreaves, \& Hargreaves (2004) menunjukkan bahwa mendengarkan musik sering menjadi kebiasaan yang menyertai pengendara dan dianggap sebagai hal yang dapat membantu pengendara untuk meningkatkan konsentrasi. Di lain pihak persepsi visual pengemudi terganggu ketika sedang berkendara bila mengunakan telepon genggam, ini dikarenakan seharusnya pengemudi fokus pada jalan. Ketika menggunakan telepon genggam pengemudi dipaksa untuk fokus pada telepon genggamnya. Hal tersebut sesuai dengan pendapat Arif (2013) yang menyatakan bahwa pada saat pengemudi mengemudikan mobil sambil menggunakan telepon genggam, maka ia dapat mengalami kebutaan sejenak sehingga mata kehilangan informasi mengenai adanya orang atau mobil di depan. Hal ini dapat mendasari kecelakaan.

Secara teoretis hasil eksperimen dengan pengenudi simulator mobil ini sesuai dengan model sumberdaya jamak dari Wickens (2008) bahwa pengendara mobil yang mendengarkan musik menggunakan dua sumberdaya berbeda yakni visual dan auditif sehingga tidak menganggu kinerja mengemudi. Sebaliknya dengan menggunakan telepon genggam untuk menerima serta membalas pesan singkat selagi mengemudikan mobil maka pengendara menggunakan sumberdaya yang sama yakni visual sehingga kinerja mengemudi akan terganggu.

\section{SIMPULAN}

Pengendara mobil yang sambil mengemudi juga mendengarkan musik lebih mampu mempersepsi dan memahami lingkungan di sekitar mobilnya sehingga mampu melakukan tindakan mengendalikan mobil, daripada pengemudi yang sambil mengemudi menggunakan telepon genggam untuk menerima serta menjawab pesan singkat.

\section{DAFTAR PUSTAKA}

Alm, H., \& Nilsson, L. (1995). The effects of a mobile telephone task on driver behaviour in the car following situation. Accident Analysis and Prevention, 27, 707-715. 
Amanda, G., \& Marbun, J. (2014, November 6). Indonesia urutan pertama peningkatan kecelakaan lalu lintas. Republika.co.id. Diunduh dari Http://www.republika.co.id/berita/nasi onal/umum/14/11/06/nem9nc-

Indonesia-urutan-pertamapeningkatan-kecelakaan-lalu-lintas.

Arif, A. (2013). Analisis terhadap penggunaan ponsel saat berkendara menurut undang-undang lalu lintas dan angkutan jalan: Studi kasus di Sat Lantas Polrestabes Makassar (Skripsi tidak diterbitkan). Universitas Hasanuddin, Makassar.

Arya, A. W., Wahyuning, C. S., \& Desrianty, A. (2014). Analisis pengaruh tempo dan genre musik terhadap kewaspadaan pengemudi mobil pribadi. Reka Integra, 3(2), 245-253.

Azwar, S. (2015). Reliabilitas dan validitas (Edisi 4). Yogyakarta: Pustaka Pelajar.

Badan Pusat Statistik. (2016). Perkembangan jumlah kendaraan bermotor menurut jenis tahun 20002013. Diunduh dari https://www.bps.go.id/linkTableDinami s/view/id/1133.

Dibben, N., \& Williamson, V. J. (2007). An exploratory survey of in-vehicle music listening. Psychology of Music, 35(4), 571-589.

Direktorat Jenderal Perhubungan DaratDepartemen Perhubungan. (2006). Faktor penyebab kecelakaan. Jakarta: Departemen Perhubungan.

Drews, F. A., Yazdani, H., Godfrey, C. N., Cooper, J. M., \& Strayer, D. L. (2009). Text messaging during simulated driving. Human Factors, 51(5), 762-770.

Endsley, M. R. (1995). A Measurement of situation awareness in dynamic systems. Human Factors, 37(1), 6584.

Endsley, M. R. (2000a). Theoretical underpinnings of situation awareness. In M. R. Endsley \& D. J. Garland (Eds.), Situation awareness: Analysis and measurement (pp 3-32). New York, NY: Lawrence Erlbaum Associates Inc.

Endsley, M. R. (2000b). Direct measurement of situation awareness: Validity and use of SAGAT. In M. R. Endsley, \& D. J. Garland (Eds.), Situation awareness: Analysis and measurement (pp. 147174). New York, NY: Lawrence Erlbaum Associates Inc.

Ghozali, I. (2011). Aplikasi analisis multivariate dengan program IBM SPSS 19 (Edisi kelima). Semarang: Universitas Diponegoro.

Gugerty, L. J. (1997). Situation awareness during driving: Explicit and implicit knowledge in dynamic spatial memory. Journal of Experimental Psychology: Applied, 3, 42-66.

Gugerty, L. J. \& Tirre. (2000). Individual differences in situation awareness. In M. R. Endsley, \& D. J. Garland (Eds.), Situation awareness: Analysis and measurement (pp. 249-274). New York, NY: Lawrence Erlbaum Associates Inc.

Hadi, S. (2015). Motedologi penelitian. Yogyakarta: Andi Offset.

Hastjarjo, T. D. (2014). Rancangan eksperimen acak. Buletin Psikologi, 22(2), 73-86.

Hendrick, D. L., Fell, J. C., \& Freedman, M. (1999). The relative frequency of unsafe driving acts in serious traffic crashes (US Department of Transport Summary Technical Report). National Highway Traffic Safety Administration. 
Lau, N., Jamieson, G. A., \& Skraaning Jr, G. (2013). Distinghuising three accounts of situation on their domains of origins. Proceedings of the Human Factors and Ergonomics Society 57 Annual Meetings. 220-227. DOI: $10.1177 / 1541931213571049$.

Matlin, M. W. (2014). Cognitive psychology ( $8^{\text {th }}$ edition). Singapore: John Wiley \& Sons Pte Ltd.

Moore, K., \& Gugerty, L. (2010). Development of novel measure of situation awareness: The case for eye movement analysis. Proceedings of the Human Factors and Ergonomics Society 54 Annual Meetings, 16501654. DOI: $10.1177 / 1541931210005401961$.

North, A. C., Hargreaves, D. J., \& Hargreaves, J. J. (2004). Uses of music in everyday life. Music
Perception: An Interdisciplinary Journal, 22(1), 41-77.

Sternberg, R. J. (1996). Cognitive psychology ( $2^{\text {nd }}$ Edition). Forth Worth, TX: Harcourt Brace College Publisher.

Treat, J. R., Tumbas, N. S., McDonald, S. T., Shinar, D., Hume, R. D., Mayer, R. E \& Castellan, N. J. (1979). Tri-level study of the causes of traffic accidents. (Final report, Executive summary). Institute for Research in Public Safety, Indiana University, Bloomington, Indiana.

Wickens, C. D. (2008). Multiple resources and mental workload. Human Factors, 50(3), 449-455. DOI: $10.15118 / 001872008 X 288394$.

Wickens, C. D., \& McCarley. J. S. (2008). Applied attention theory. Boca Raton, FL: CRC Press Taylor \& Francis Group. 